\title{
COMBINED APS/SPR PLENARY SESSION
}

$$
\text { Wednesday, May 2, 1984, 1:30 PM }
$$

Continental Ba11room 1-9

1:30 - 2:00 PM PRESENTATION OF THE HOWLAND AWARD TO HENRY L. BARNETT, M.D. BY NORMAN KRETCHMER, M.D.

Moderator: Joseph Dancis, M.D.

2:00 PM THE EFFECTS OF HYPOXEMIA AND HYPOTENSION ON LOCAL CEREBRAL GLUCOSE UTILIZATION IN THE AWAKE NEWBORN PUPPY. J.F. Pasternak, K. Schlageter, R. Hayden (Spon. C. Hunt), Div. of Neuro., Evanston Hosp., Evanston. (1454)

2:20 PM PROSTAGLANDIN-MEDIATED CONTROL OF NEONATAL CEREBRAL BLOOD FLOW. Laura R. Ment, William B. Stewart, Charles C. Duncan, Bruce Pitt (Spon. by G. Lister), Yale Univ. Sch. of Med., Dept. Ped., Neuro., Neurosurg., Anesth., New Haven. (1704)

2:40 PM EFFECTS OF LABOR AND AIR-BREATHING ON CATION EXCHANGE IN LUNG EPITHELIAL CELLS OF BABY BUNNIES. R.D. Bland and C.A.R. Boyd. Cardiovasc. Res. Inst., Dept. Ped., Univ. of Calif., San Francisco; Dept. of Human Anat., Univ. of Oxford, UK. (1743)

3:00 PM INTERMISSION

3:20 PM VARICELLA VACCINE: PROTECTIVE EFFICACY IN CHILDREN WITH LEUKEMIA. Anne A. Gershon, Sharon P. Steinberg Angelo Ferrara, William Borkowsky, Philip LaRussa, Lawrence Gelb, George Galasso, \& NIAID Collab. Study Group, Dept. Ped., NYU Med. Ctr., NY, Dept. Med., Wash. Univ., St. Louis, \& NIH, Bethesda. (1075)

3:40 PM RESPONSE TO VACCINE AND RISK OF HAEMOPHILUS TYPE B (HIB) DISEASE IN CHILDREN WITH THE KM(1) IMMUNOGLOBULIN (IG) ALLOTYPE. Dan M. Granoff, Janardan P. Pandey, Eyla G. Boies, Janet E. Squires, Robert S. Munson, Jr. and Brian Suarez, Wash. Univ. Sch. of Med., St. Louis. (1079)

4:00 PM STATE-OF-THE-ART ADDRESS: Richard A. Lerner, M.D. ANTIBODIES OF PREDETERMINED SPECIFICITY. 


\section{COMBINED APS/SPR PLENARY SESSION}

Thursday, May 3, 1984, 1:30 PM Continental Ballroom 1-9

1:30 - 2:00 PM APS PRESIDENTIAL ADDRESS - Joseph Dancis, M.D.

Moderator: John D. Johnson, M.D.

2:00 PM AMINO ACIDS ARE POTENT INHIBITORS OF BILE ACID UPTAKE BY LIVER PLASMA MEMBRANE VESICLES ISOLATED FROM SUCKLING RATS. John C. Bucuvalas, Anita L. Goodrich, Bennett L. Blitzer, Frederick J. Suchy (Spon. by William R. Balistreri), Univ. of Cincinnati Coll. of Med., Dept. of Ped. and Med., Cincinnati. (573)

2:20 PM ACHONDROPLASIA DUE TO DNA INSERTION INTO THE TYPE II COLLAGEN GENE. Charles M. Strom (Spon. by Lawrence M. Gartner) Univ. of Chicago, Pritzker Sch. of Med., Dept. of Ped., Chicago. (784)

2:40 PM BIOSYNTHESIS AND POSTSYNTHETIC ASSEMBLY OF HUMAN C REACTIVE PROTEIN (CRP). E.C. Mantzouranis, G. Goldberger, L.A. Potempa, A.S. Whitehead, H. Gewurz, H.R. Colten, Harvard Med. Sch., Boston, and Rush Med. Coll., Chicago. (987)

\section{3:00 PM INTERMISSION}

3:20 PM GENE DELETION AND RESTRICTION FRAGMENT LENGTH POLYMORPHISM (RFLP) AT THE HUMAN ORNITHINE TRANSCARBAMY LASE (OTC) LOCUS. R. Rozen, A. Horwich, W.A. Fenton, L.E. Rosenberg. Dept. of Human Genet. and Ped., Yale Med. Sch., New Haven. (775)

3:40 PM IDENTIFICATION AND CLONING OF GENES RESPONSIBLE FOR MULTIPLE DRUG RESISTANCE. H.T. Abelson, I.B. Roninson, N. Howe 1 1, P. Gros, A.J. Varshavsky, and D.E. Housman, Dana-Farber Cancer Inst., Boston, and Mass. Inst. of Tech., Cambridge. (832)

4:00 PM STATE-OF-THE-ART ADDRESS: Steven Martin, M.D., Dept. of Zoology, Univ. of Calif. Berkeley, ONCOGENES AND CANCER 
Friday, May 4, 1984, 8:30 AM

Continental Ballroom 1-9

\begin{abstract}
8:30 - 9:00 AM SPR PRESIDENTIAL ADDRESS - John D. Johnson, M.D.
9:00 - 9:30 AM SECOND ANNUAL YOUNG INVESTIGATORS AWARD -

Stylianos Antonarakis, M.D., Presentation by

John D. Johnson, M.D., President, SPR.

DNA POLYMORPHISM ANALYSIS IN THE BETA-GLOBIN

GENE CLUSTER: USE IN THE DISCOVERY OF MOLECULAR

DEFECTS OF BETA-THALASSEMIA IN MAN.
\end{abstract}

\title{
PLENARY SESSION
}

Moderators: Mildred Stahlman, M.D. and Thomas Boat, M.D.

9:30 AM ABLATION OF THE MATERNAL SUPRACHIASMATIC NUCLEI DISRUPTS THE TIMING OF THE FETAL CIRCADIAN CLOCK. S.M. Reppert and W.J. Schwartz, Children's and Neuro. Serv., Mass. Gen. Hosp., Boston. (291)

9:50 AM EFFECTS OF EXERCISE TRAINING ON INSULIN SENSITIVITY IN ADOLESCENTS WITH TYPE I DIABETES (IDDM). Kyle W. Landt, Barbara N. Campaigne, Frederick W. James and Mark A. Sperling, Dept. of Ped., Children's Hosp. Med. Ctr., Univ. of Cincinnati. (13)

$10: 10$ AM INTERMISSION

10:30 AM DIABETES MELLITUS AND VASCULAR DISEASE: POSSIBLE ROLE OF HYDROXYACIDS IN ITS GENESIS. M. Stuart, J. Graeber, Y. Setty, R. Walenga, T. Conner, B. Glaser. Upstate Med. Ctr., Syracuse, and Johns Hopkins Hosp., Baltimore. (1228)

10:50 AM USE OF P-31 NMR IN DIAGNOSIS AND THERAPY OF A FAMILIAL CARDIOMYOPATHY. Glenn Whitman, Britton Chance, B.J. Clark, Richard Kelley, John Maris, Alden Marken, Hans Bode. The Med. Sch. of the Univ. of Penn., Phila. and Harvard Med. Sch., Boston. (1240)

11:10 AM STATE-OF-THE-ART ADDRESS: Robert G. Shulamn, Ph.D. NMR STUDIES OF METABOLISM IN VIVO.

The Society for Pediatric Research acknowledges the generous contribution of the Journal of Pediatrics Education Program in support of the State-of-the-Art lecture series. 